\title{
An application of TOPSIS for selection of appropriate e-Governance practices to improve cus- tomer satisfaction
}

\author{
Ajinkya Joshia ${ }^{*}$, Vinayak Deshpande ${ }^{\mathrm{b}}$ and Padmakar Pawar ${ }^{\mathrm{c}}$
}

${ }^{a}$ Assistant Professor and I/C Registrar, K. K. Wagh Institute of Engineering Education and Research, Nashik, India

${ }^{b}$ Head, Department of Business Management, Rashtrasant Tukadoji Maharaj Nagpur University, Nagpur, India

${ }^{c}$ Head Production Engineering Department, K. K. Wagh Institute of Engineering Education and Research, Nashik, India

\section{CHRON I C L E A B S T RACT}

Article history:

Received: March 5, 2017

Received in revised format: July

16,2017

Accepted: July 28, 2017

Available online:

July 29, 2017

Keywords:

Customer satisfaction

e-Governance practices

Standardized process

Multiple-criteria decision analysis TOPSIS

G2C

\begin{abstract}
E-governance practices and standardization of processes are significant factors affecting the performance of government organizations and undertakings in India. Customer is the backbone of any organization and customer satisfaction is the key for ensuring the success. Using a multiplecriteria decision analysis method named TOPSIS, we attempt to study the impact of e-governance practices on customer satisfaction of Maharashtra Housing and Area Development Authority (MHADA). The method determines the ranking and contribution of different elements in an attempt to determine a suitable strategy for every customer segment. Results show that customers belonging to Higher Income Group (HIG) and Middle Income Group (MIG) are more satisfied with the Online Mitra Service while the customers of Lower Income Group (LIG) and Economic Weaker Section (EWS) are more inclined towards Process Standardization. In order to remove bias and obtain fairly accurate results the data were collected through questionnaire from every customer segment.
\end{abstract}

\section{Introduction}

Housing not only provides shelter but also a sense of satisfaction and superiority in the society (Mary \& Surulivel 2014). Customer satisfaction is an important factor for the development of construction process and customer relationship (Rathod et al., 2016). The findings of Garg et al. (2014) suggest that customer satisfaction for new housing is something more than the technical quality of constituent components of a house. Mustafa and Ghazali (2012) examined multiple concepts associated with customer satisfaction in the Malaysian housing industry. It is observed that almost all governments in the world are transforming from traditional service to e-service (Shang, 2014). E-government refers to the delivery of information and services through internet or other digital means and permit citizens to obtain information as per their convenience (West, 2004).

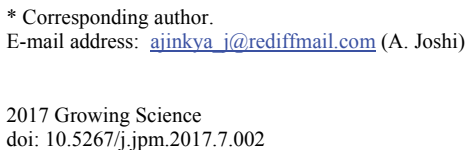


E-Governance is the public sector's use of information and communication technologies with the aim of improving information and service delivery, encouraging citizen participation in the decision-making process and making government more accountable, transparent and effective (UNESCO). Dwivedi and Bharti (2010) define e-Governance as "the implementation and delivery of government services through the information communication technology to provide Transparent, Effective, Efficient, Responsive and Accountable governance to the society. In simple words, e-Governance is the utilization of Information and Communication Technology (ICT) for providing government services and exchange of information between Government and Customer (Citizens), Government and Business and between Government and Government". E-governance has the potential to improve customer satisfaction (Naz, 2009). The main objective of e-governance is to make the government services available to the citizens in the most convenient, efficient, affordable and transparent manner (Singla \& Aggarwal 2014).

A standard is a document, established by consensus and approved by a recognized body, which provides, for common and repeated use, rules, guidelines or characteristics for activities or their results, aimed at the achievement of the optimum degree of order in a given context (Hatto, 2010). There are at least five main benefits of standardization. These include efficiency, accuracy, greater coherence and comparability of data across the organization, improved level of process and outputs and positioning of the organization to be responsive to new requirements and relevance (Linacre, 2011). Standardization ensures that the end product delivers consistent quality and the final results are comparable with other similar items of the same class. Lack of standardization makes coordination a difficult task.

Maharashtra Housing and Area Development Authority (MHADA) was constituted by the MHADA ACT of 1976 under the Housing Department, Government of Maharashtra with an aim to provide comprehensive and coordinated approach to the housing problems faced by the people in the state of Maharashtra. As MHADA offers housing units to the customers at a cheaper rate, the number of applicants in every city is much higher than the number of housing units that are constructed by MHADA. In order to provide equal opportunity for all applicants interested in obtaining a housing unit, the available housing units are allotted by conducting a lottery. Computerized lottery (E-Lottery) has been implemented in Mumbai and Konkan Board since 2013 and 2014, respectively and has recently been introduced in Pune Board. All other boards still adopt a manual lottery system. MHADA has started providing some e-services such as availability of personal profile, online query, online submission of documents, online payment, SMS alerts, etc. to the customers who have obtained a house through e-lottery. However these services are yet to be extended to customers securing a house through manual lottery system. To provide efficient services to the customers, the organization has also launched a feature named "MHADA's Initiative for Transparent and Responsive Action" (MITRA). Some e-services are being provided to the customers through this e-Mitra feature. A recent study has revealed that e-governance practices and standardized processes are significant factors influencing the performance of government organizations and undertakings in India (Joshi et.al, 2017).

A well-known and widely used method of multi-criteria decision analysis - TOPSIS has been employed to select appropriate e-governance practices extended by MHADA to the different customer segments namely High Income Group (HIG), Middle Income Group (MIG), Low Income Group (LIG) and Economically Weaker Section (EWS).

\section{Literature Review}

A research on user satisfaction of an e-Government portal providing agricultural services was undertaken by Bournaris et al. (2013) using MUlticriteria Satisfaction Analysis (MUSA) method. The researchers evaluated five criteria and have observed that weight for the criteria accessibility and interaction are the highest. By combining the weights of satisfaction criteria with average satisfaction indices, researchers have provided a diagrammatic representation highlighting strengths and weaknesses of customer satisfaction besides areas in which improvement efforts are required. 
A research was undertaken to study the satisfaction of citizens towards e-Governance initiative SETU of Government of Maharashtra (Warale \& Diwakar 2015). Separate questionnaires were designed for citizens and service providers. A survey based approach was adopted and the data were obtained from 977 respondents across three districts of the state. The responses were used to evaluate the SETU initiative in terms of eight parameters namely timeliness, cooperation, ease of use, promptness, accuracy, privacy, transparency and cost. Findings revealed that there had been a significant positive relationship between quality of services and citizen's satisfaction and that the citizens are overall satisfied with the services, delivery mechanism and management at the centers. The study also pointed out that the objectives set by the government are yet to be accomplished. Yaghoubi et al. (2011) carried out a research to evaluate e-government performance in delivering electronic services through ICT offices in Mashhad, Iran. Opinion of 402 clients of Mashhad Communication Centers was collected using a questionnaire. Assessment of customer opinion about services offered by ICT offices was carried out using MUSA model and five customer satisfaction criteria were evaluated. Results indicate that although customer satisfaction for type, accessibility and delivery of service is more than the average, customers are not satisfied with the staff of ICT offices.

Findings of research on linking citizen satisfaction with e-government suggest that individuals using the government websites are not just critical consumers but are also demanding citizens and appear to be satisfied with the implementation of e-government (Welch et al., 2005). E-government can increase trust by improving interactions with the citizens (Tolbert \& Mossberger, 2006). E-governance initiatives also help in reducing corruption (Singh et. al., 2010; Mistry \& Jalal 2012). It is believed that interaction of citizens with the government has improved due to the use of internet (Reddick, 2005). MHADA is perhaps the only government undertaking in the state which provides similar product to different income groups at different prices. The primary aim of MHADA is not to earn profits but to provide affordable housing to various sections of the society. The revised rates for associated costs and profit that are considered while finalizing the selling price of the housing unit are as follows:

\section{Table 1}

Revised rate for various income groups (Source: MHADA Circular)

\begin{tabular}{|c|c|c|c|c|}
\hline \multirow[t]{2}{*}{ Sr. No. } & \multirow[t]{2}{*}{ Element } & \multirow[t]{2}{*}{ Customer Segment } & \multicolumn{2}{|c|}{ Revised rates for } \\
\hline & & & Mumbai & Other boards \\
\hline \multirow{2}{*}{1.} & \multirow{2}{*}{ Administrative charges } & EWS and LIG & $5 \%$ & $3 \%$ \\
\hline & & MIG and HIG & $10 \%$ & $4 \%$ \\
\hline \multirow{3}{*}{2.} & \multirow{3}{*}{ Profit } & EWS and LIG & Nil & Nil \\
\hline & & MIG & Ready Recknor rate + $5 \%$ & $5 \%$ \\
\hline & & HIG & Ready Recknor rate $+10 \%$ & $10 \%$ \\
\hline
\end{tabular}

Past research indicates that there was a strong relationship between e-Governance practices and customer satisfaction. Much research has been carried out to evaluate the impact of e-services on customer satisfaction. However a need has been felt to analyze the impact of the e-services on different customer segments so that separate policy can be formulated to cater every segment. Formulating separate policy for every income group will have a greater impact on the customer satisfaction. By employing a multiple-criteria decision analysis method TOPSIS, an attempt is made to study the impact of e-governance practices and standardized processes on customer satisfaction of different customer segments.

\section{Methodology}

\section{a. Variables identified as criteria for customer satisfaction}

Satisfaction is the customer's sense that consumption provides outcomes against a standard of pleasure versus displeasure (Oliver 1999). Customer is the king and therefore customer satisfaction is the topmost priority of any organization. Oliver (1993) stated that customers are more satisfied when they perceive fair (equitable) treatment and when they attribute favorable outcome for themselves and unfavorable outcome for others. Customers will be dissatisfied, if the products and services delivered only 
the basic needs and levels of essential need fulfillment are not exciting (Oliver et al., 1997). Customer satisfaction is a meaningful objective feedback about the product and services. Various elements of customer satisfaction considered in the proposed study are shown in Fig. 1. It includes twelve elements grouped in three main categories.

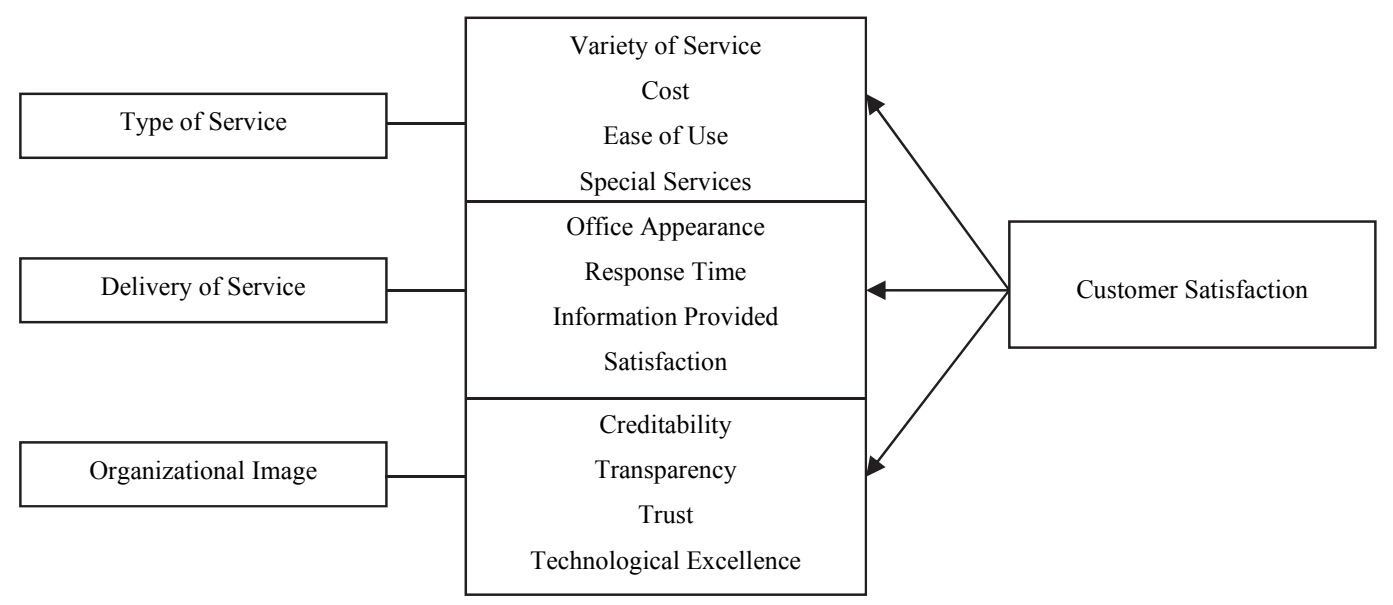

Fig. 1. Elements of customer satisfaction

The three main categories namely Type of Service, Delivery of Service and Organizational Image were mapped with E- Mitra, E- lottery and Standardized Processes and $3 \times 3$ matrices (separate for every income group) were prepared. The customer responses obtained from the questionnaire were tabulated in an excel sheet and the average value was used to complete the matrix.

\section{b. Technique for Order of Preference by Similarity to ideal Solution (TOPSIS)}

The technique for Order of Preference by Similarity to ideal Solution (TOPSIS) is a multi criteria decision analysis method originally developed by Hwang and Yoon (1981). The technique is based on the concept that the best alternative has the shortest geometric distance from the positive ideal solution (PIS) and has the longest geometric distance from the ideal negative solution (NIS). A PIS maximizes the benefit criteria / attributes and minimizes the benefit criteria. On the other hand NIS maximizes the cost criteria and minimizes the benefit criteria. Following are the important steps of TOPSIS (Rao 2007):

Step 1: Identifying evaluation attributes

Determine the objectives and identify the evaluation attributes for the study.

Step 2: Create evaluation matrix and obtain normalized decision matrix

Prepare an evaluation (decision) matrix consisting of $m$ attributes and $n$ criteria. The intersection of every attribute and criteria is given as $x_{i j}$. Normalize the decision matrix using the following equation:

$$
R_{i j}=\frac{x_{i j}}{\sqrt{\sum_{j=1}^{M} x_{i j}^{2}}}
$$

where $\quad i=1,2, \ldots . m$ and $\quad j=1,2, \ldots . n$

\section{Step 3: Obtain weighted normalized matrix}

Decide the relative importance (i.e. weights) of various attributes with respective to the objective in such a way that the sum weights of all attributes equals to 1 . 


$$
\sum_{i=1}^{n} w_{i}=1
$$

Thereafter obtain the weighted normalized matrix by multiplying the normalized decision matrix by its associated weights. The weighted normalized decision matrix is formed as

$$
V_{i j}=w_{j} \times R_{i j}
$$

where $i=1,2, \ldots . . m, j=1,2, \ldots . n$ and $w_{j}$ represents weight of the $j^{\text {th }}$ attribute.

Step 4: Determine positive ideal $(V+)$ and negative ideal $(V-)$ solution

The positive ideal solution (PIS) and negative ideal solution (NIS) are determined as follows:

$$
V^{+}=\left(V_{1}^{+}, V_{2}^{+}, \ldots, V_{n}^{+}\right) \text {maximum values and } V^{-}=\left(V_{1}^{-}, V_{2}^{-}, \ldots, V_{n}^{-}\right) \text {minimum values }
$$

Step 5: Calculate separation measures using n-dimensional Euclidean distance

Separation of every alternative from the positive ideal solution (PIS) and negative ideal solution (NIS) is calculated using following formulae:

$$
S_{j}^{+}=\sqrt{\sum_{i=1}^{n}\left(V_{i j}-V_{i}^{+}\right)^{2}} \text { and } S_{j}^{-}=\sqrt{\sum_{i=1}^{n}\left(V_{i j}-V_{i}^{-}\right)^{2}}
$$

where $j=1,2, \ldots, \mathrm{N}$.

Step 6: Calculate closeness coefficient $(P)$

Closeness coefficient $\left(\mathrm{P}_{\mathrm{j}}\right)$ for every strategy is calculated as follows:

$$
P_{j}=\frac{S_{j}^{-}}{S_{j}^{+}+S_{j}^{-}}
$$

Step 7: Determine percentage contribution of strategy:

The percentage contribution of every strategy is calculated as follows:

$$
P C_{j}=\frac{P_{j}}{\sum P_{j}} \times 100
$$

\section{c. Data Collection:}

MHADA coordinates and controls the activities of seven regional housing boards setup for each revenue division in the state of Maharashtra viz. Mumbai, Konkan, Pune, Nashik, Nagpur, Amravati, Aurangabad and two special purpose boards viz. Mumbai Building Repairs and Reconstruction Board (MBR\&R) and Mumbai Slum Improvement Board (MSIB). These regional boards differ in terms of demography, climatic conditions, quality of people, industry, size, population etc.

Out of the nine boards of MHADA, seven regional boards that are directly involved in providing housing to the customers have been selected for the study. The remaining two special purpose boards viz. Mumbai Building Repairs and Reconstruction Board (MBR\&R) and Mumbai Slum Improvement Board (MSIB) undertake a different activity of repair and reconstruction of dilapidated buildings and slum improvement respectively and therefore fall beyond the scope of this work. A separate research 
on these two special purpose boards can be initiated. In order to remove bias and obtain fairly accurate results the data were collected through a structured questionnaire from 336 customers of seven boards selected on a random basis (twelve customers per income group per board). Attributes were mapped with the strategies and the average of related customer responses was used to prepare a matrix. The outcome of this study can be used to suggest an effective strategy for every income group and board. The study also reveals opinion and customer expectations of various income groups.

\section{Application Example}

\section{Step 1: Identifying evaluation attributes}

Twelve elements of customer satisfaction were considered and grouped in three main categories (attributes) namely type of service, delivery of service and organizational image as shown in Fig. 1. Opinion obtained from the customers was converted on a scale of $0-1$ and tabulated in a spreadsheet. The average value obtained from the spreadsheet was used to prepare the individual evaluation matrix. Accordingly twenty eight evaluation matrices (one per income group per board) were prepared.

\section{Step 2: Obtaining a normalized decision matrix}

In the next step, twenty eight normalized decision matrices were prepared using Eq. (1). The normalized matrix for Nagpur board has been shown in Table 2:

Table 2

Normalized matrix for Nagpur Board

\begin{tabular}{|c|c|c|c|c|c|c|c|c|c|c|c|c|}
\hline \multirow[t]{2}{*}{ Strategies } & \multicolumn{3}{|c|}{ Normalized matrix for HIG Nagpur } & \multicolumn{3}{|c|}{ Normalized matrix for MIG Nagpur } & \multicolumn{3}{|c|}{ Normalized matrix for LIG Nagpur } & \multicolumn{3}{|c|}{ Normalized matrix for EWS Nagpur } \\
\hline & $\begin{array}{l}\text { Type of } \\
\text { Service }\end{array}$ & $\begin{array}{c}\text { Delivery } \\
\text { of Ser- } \\
\text { vice }\end{array}$ & $\begin{array}{l}\text { Org. Im- } \\
\text { age }\end{array}$ & $\begin{array}{l}\text { Type of } \\
\text { Service }\end{array}$ & $\begin{array}{c}\text { Delivery } \\
\text { of Ser- } \\
\text { vice }\end{array}$ & $\begin{array}{l}\text { Org. Im- } \\
\text { age }\end{array}$ & $\begin{array}{l}\text { Type of } \\
\text { Service }\end{array}$ & $\begin{array}{c}\text { Delivery } \\
\text { of Ser- } \\
\text { vice }\end{array}$ & $\begin{array}{l}\text { Org. Im- } \\
\text { age }\end{array}$ & $\begin{array}{l}\text { Type of } \\
\text { Service }\end{array}$ & $\begin{array}{c}\text { Delivery } \\
\text { of Ser- } \\
\text { vice }\end{array}$ & $\begin{array}{l}\text { Org. Im- } \\
\text { age }\end{array}$ \\
\hline Online MITRA & 0.570440 & 0.568961 & 0.599980 & 0.618145 & 0.534364 & 0.646843 & 0.435100 & 0.534246 & 0.667674 & 0.447816 & 0.339075 & 0.619166 \\
\hline E-Lottery & 0.570960 & 0.587718 & 0.565696 & 0.534339 & 0.604675 & 0.523635 & 0.675400 & 0.472939 & 0.558219 & 0.565424 & 0.542520 & 0.633238 \\
\hline $\begin{array}{l}\text { Standardization } \\
\text { Of Processes }\end{array}$ & 0.590425 & 0.575213 & 0.565696 & 0.576523 & 0.590613 & 0.5544371 & 0.595419 & 0.70061 & 0.4925467 & 0.692644 & 0.76857 & 0.46437 \\
\hline
\end{tabular}

Step 3: Obtaining weighted normalized matrix

It was assumed that all the attributes are equally important. Hence equal weights $(0.33)$ were assigned to every attribute and accordingly, twenty eight weighted normalized matrices were prepared using Eq. (2). The weighted normalized matrix for Nagpur board has been shown in Table 3:

Table 3

Weighted normalized matrix for Nagpur Board

\begin{tabular}{|c|c|c|c|c|c|c|c|c|c|c|c|c|}
\hline \multirow[t]{2}{*}{ Strategies } & \multicolumn{3}{|c|}{$\begin{array}{l}\text { Weighted normalized matrix for } \\
\text { HIG Nagpur }\end{array}$} & \multicolumn{3}{|c|}{$\begin{array}{c}\text { Weighted normalized matrix for MIG } \\
\text { Nagpur }\end{array}$} & \multicolumn{3}{|c|}{$\begin{array}{c}\text { Weighted normalized matrix for LIG } \\
\text { Nagpur }\end{array}$} & \multicolumn{3}{|c|}{$\begin{array}{c}\text { Weighted normalized matrix for EWS } \\
\text { Nagpur }\end{array}$} \\
\hline & $\begin{array}{c}\text { Type } \\
\text { of Ser- } \\
\text { vice }\end{array}$ & $\begin{array}{l}\text { Delivery } \\
\text { of Service }\end{array}$ & $\begin{array}{l}\text { Org. Im- } \\
\text { age }\end{array}$ & $\begin{array}{l}\text { Type of } \\
\text { Service }\end{array}$ & $\begin{array}{l}\text { Delivery } \\
\text { of Ser- } \\
\text { vice }\end{array}$ & $\begin{array}{l}\text { Org. Im- } \\
\text { age }\end{array}$ & $\begin{array}{l}\text { Type of } \\
\text { Service }\end{array}$ & $\begin{array}{l}\text { Delivery } \\
\text { of Ser- } \\
\text { vice }\end{array}$ & $\begin{array}{l}\text { Org. Im- } \\
\text { age }\end{array}$ & $\begin{array}{l}\text { Type of } \\
\text { Service }\end{array}$ & $\begin{array}{c}\text { Delivery } \\
\text { of Ser- } \\
\text { vice }\end{array}$ & $\begin{array}{l}\text { Org. Im- } \\
\text { age }\end{array}$ \\
\hline $\begin{array}{l}\text { Online MI- } \\
\text { TRA }\end{array}$ & 0.188 & 0.1878 & 0.198 & 0.204 & 0.176 & 0.213 & 0.1436 & 0.1763 & 0.220 & 0.1478 & 0.1119 & 0.204 \\
\hline E-Lottery & 0.188 & 0.194 & 0.187 & 0.176 & 0.199 & 0.173 & 0.2229 & 0.156 & 0.184 & 0.1866 & 0.179 & 0.209 \\
\hline $\begin{array}{l}\text { Standardiza- } \\
\text { tion Of Pro- } \\
\text { cesses }\end{array}$ & 0.195 & 0.1899 & 0.1867 & 0.190 & 0.195 & 0.183 & 0.196 & 0.231 & 0.163 & 0.229 & 0.254 & 0.153 \\
\hline
\end{tabular}

Step 4: Determining positive ideal $(V+)$ and negative ideal $(V-)$ solution

The values for positive and negative ideal solution were determined using equation 3 . The values of PIS and NIS obtained for Nagpur Board have been shown in table no. 4: 
Table 4

Values for Positive and Negative ideal solution of Nagpur Board

\begin{tabular}{ccccccccccccc}
\hline $\begin{array}{c}\text { PIS / } \\
\text { NIS }\end{array}$ & \multicolumn{3}{c}{ HIG Nagpur } & \multicolumn{3}{c}{ MIG Nagpur } & \multicolumn{3}{c}{ LIG Nagpur } & \multicolumn{3}{c}{ EWS Nagpur } \\
\hline (PIS) & 0.19484 & 0.19395 & 0.198 & 0.204 & 0.1995 & 0.2134 & 0.2229 & 0.2312 & 0.2203 & 0.2286 & 0.2536 & 0.209 \\
V + & & & & & & & & & & & & \\
(NIS) & 0.1882 & 0.1878 & 0.1867 & 0.176 & 0.1763 & 0.1728 & 0.1436 & 0.1561 & 0.1625 & 0.1478 & 0.1119 & 0.153 \\
V - & & & & & & & & & & & & \\
\hline
\end{tabular}

Step 5: Calculation of separation measures using n-dimensional Euclidean distance

Separation of every alternative from the positive and negative ideal solution was carried out using equation no. 4. The separation values $\mathrm{S}+$ and $\mathrm{S}$ - obtained for Nagpur Board are shown in table no. 5:

Table 5

Separation values for every alternative - Nagpur Board

\begin{tabular}{cccccc}
\hline \multirow{2}{*}{ Separation value from } & \multicolumn{4}{c}{ Separation value for Nagpur Board } \\
\cline { 3 - 6 } & & HIG & MIG & LIG & EWS \\
\hline \multirow{3}{*}{ PIS } & S1 & 0.00904455 & 0.02320261 & 0.09645640 & 0.163209866 \\
& S2 & 0.01301003 & 0.04917313 & 0.08337497 & 0.085598811 \\
& S3 & 0.0120429 & 0.03376499 & 0.06353409 & 0.05572505 \\
\hline \multirow{2}{*}{ NIS } & S1 & 0.01131380 & 0.04917313 & 0.06123101 & 0.051081268 \\
& S2 - & 0.00619217 & 0.02320261 & 0.08220723 & 0.09549306 \\
& S3 - & 0.00690991 & 0.02533116 & 0.09190030 & 0.163143788 \\
\hline
\end{tabular}

The above steps were repeated for other boards namely Amravati, Aurangabad, Konkan, Mumbai, Nashik and Pune.

Step 6: Calculation of closeness coefficient $(P)$ and percentage contribution

Using the separation values of PIS and NIS, closeness coefficient was calculated with the help of Eq. (5). Finally percentage contribution of every strategy was calculated using Eq. (6). The percentage contribution of each strategy for all income groups is shown in Tables (6a-6c).

Table 6a

Percentage contribution of every strategy (Amravati and Aurangabad Board)

\begin{tabular}{ccccccccc}
\hline Strategy & \multicolumn{3}{c}{ Percentage contribution for Amravati Board } & \multicolumn{3}{c}{ Percentage contribution for Aurangabad Board } \\
\cline { 2 - 9 } & HIG & MIG & LIG & EWS & HIG & MIG & LIG & EWS \\
\hline Online MITRA & 45.03 & 46.27 & 28.06 & 47.85 & 44.46 & 53.19 & 34.97 & 25.47 \\
E-Lottery & 37.09 & 31.54 & 26.54 & 19.95 & 39.74 & 29.92 & 16.15 & 30.94 \\
Standardization of Processes & 17.88 & 22.19 & 45.4 & 32.2 & 15.8 & 16.89 & 48.88 & 43.59 \\
\hline
\end{tabular}

Table 6b

Percentage contribution of every strategy (Konkan and Mumbai Board)

\begin{tabular}{ccccccccc}
\hline Strategy & \multicolumn{2}{c}{ Percentage contribution for Konkan Board } & \multicolumn{3}{c}{ Percentage contribution for Mumbai Board } \\
\cline { 2 - 7 } & HIG & MIG & LIG & EWS & HIG & MIG & LIG & EWS \\
\hline Online MITRA & 41.01 & 47.19 & 34.01 & 12.10 & 35.38 & 45.83 & 9.39 & 13.43 \\
E-Lottery & 34.30 & 18.08 & 13.88 & 41.05 & 36.75 & 40.05 & 34.87 & 41.67 \\
Standardization of Processes & 24.69 & 34.73 & 52.11 & 46.85 & 27.87 & 14.12 & 55.74 & 44.9 \\
\hline
\end{tabular}

Table 6c

Percentage contribution of every strategy (Nagpur, Nashik and Pune Board)

\begin{tabular}{|c|c|c|c|c|c|c|c|c|c|c|c|c|}
\hline \multirow[t]{2}{*}{ Strategy } & \multicolumn{4}{|c|}{$\begin{array}{c}\text { Percentage contribution for Nagpur } \\
\text { Board }\end{array}$} & \multicolumn{4}{|c|}{$\begin{array}{l}\text { Percentage contribution for Nashik } \\
\text { Board }\end{array}$} & \multicolumn{4}{|c|}{$\begin{array}{l}\text { Percentage contribution for Pune } \\
\text { Board }\end{array}$} \\
\hline & HIG & MIG & LIG & EWS & HIG & MIG & LIG & EWS & HIG & MIG & LIG & EWS \\
\hline Online MITRA & 44.72 & 47.56 & 26.31 & 15.77 & 42 & 42.89 & 29.63 & 21.03 & 41.91 & 42.87 & 19.9 & 39.39 \\
\hline E-Lottery & 25.95 & 22.44 & 33.63 & 34.9 & 36.87 & 28.82 & 33.45 & 37.58 & 20.13 & 26.37 & 35.04 & 16.92 \\
\hline $\begin{array}{l}\text { Standardization of Pro- } \\
\text { cesses }\end{array}$ & 29.33 & 30 & 40.06 & 49.33 & 21.13 & 28.29 & 36.92 & 41.39 & 37.96 & 30.76 & 45.06 & 43.69 \\
\hline
\end{tabular}

Above results indicate that that the percentage contribution of Online Mitra for High and Middle income group is higher than percentage contribution for E-lottery and Standardized Process whereas the 
percentage contribution of Standardized Process for Low Income Group and Economically Weaker Section is higher than the percentage contribution for Online Mitra and E-lottery. The only exception to the above observation is EWS customers of Amravati and HIG customers of Mumbai Board. Customers of EWS Amravati are more inclined towards Online Mitra while those of HIG Mumbai Board are marginally inclined towards E-lottery.

\section{Other expectations}

Other expectations of the four income groups were also collected through the questionnaire survey. These include preferred mode of communication with the organization, factors influencing the purchase of housing from the organization, additional e-facilities that should be provided by the organization etc. These expectations are briefly discussed as follows:

\section{a. Preferred mode of communication with MHADA:}

Customers were asked about the preferred mode(s) of communication with MHADA such as personal visit to the office, by telephonic call, through surface mail, through e-mail and other sources e.g. friends / relatives / agents etc. Most of the customers preferred multiple modes for communication. Responses of the customers reveal that majority of the customers of all income groups prefer visiting the organization directly for solving their problems followed by making a telephonic call. The responses of the customers about the preferred mode of communication with MHADA office are shown in the Fig 2.

Demographic variables play an important role in selecting channels of communication (Reddick \& Jaramillo 2014). It has been observed that most of the customers prefer visiting the organization or making a telephone call for contacting the organization. It should be noted that majority of the customers (especially those belonging to lower income group and economically weaker section) are not conversant with the use of computers and or do not have access to basic computing facilities. This appears to be one of the reasons why e-mail is not a preferred mode of communication.

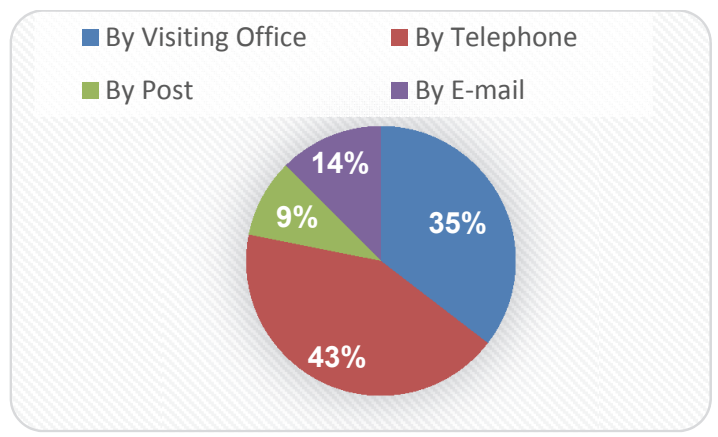

Amravati region

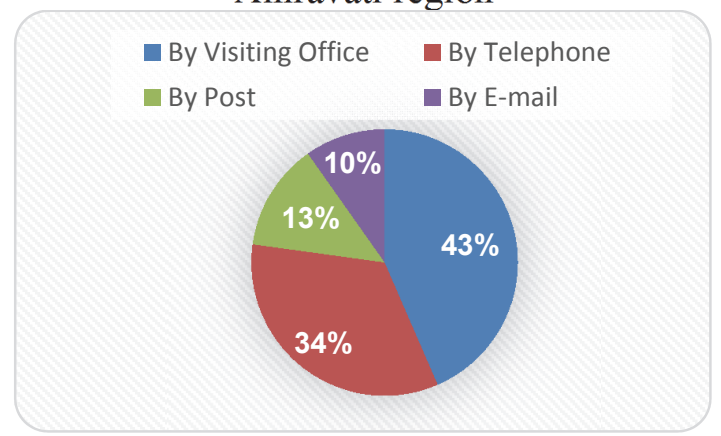

Konkan region

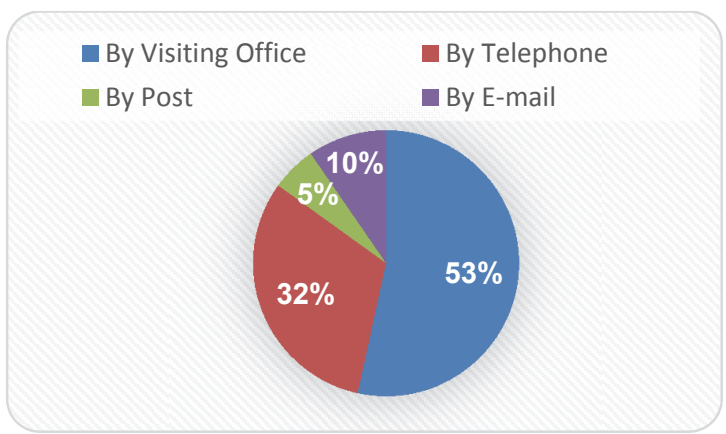

Aurangabad region

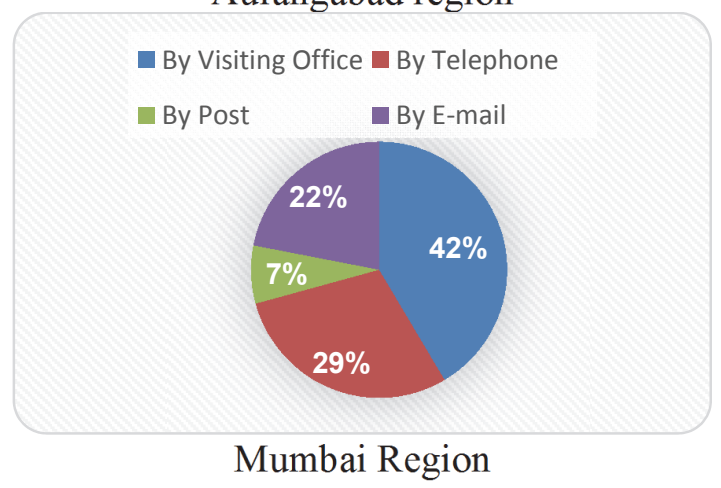




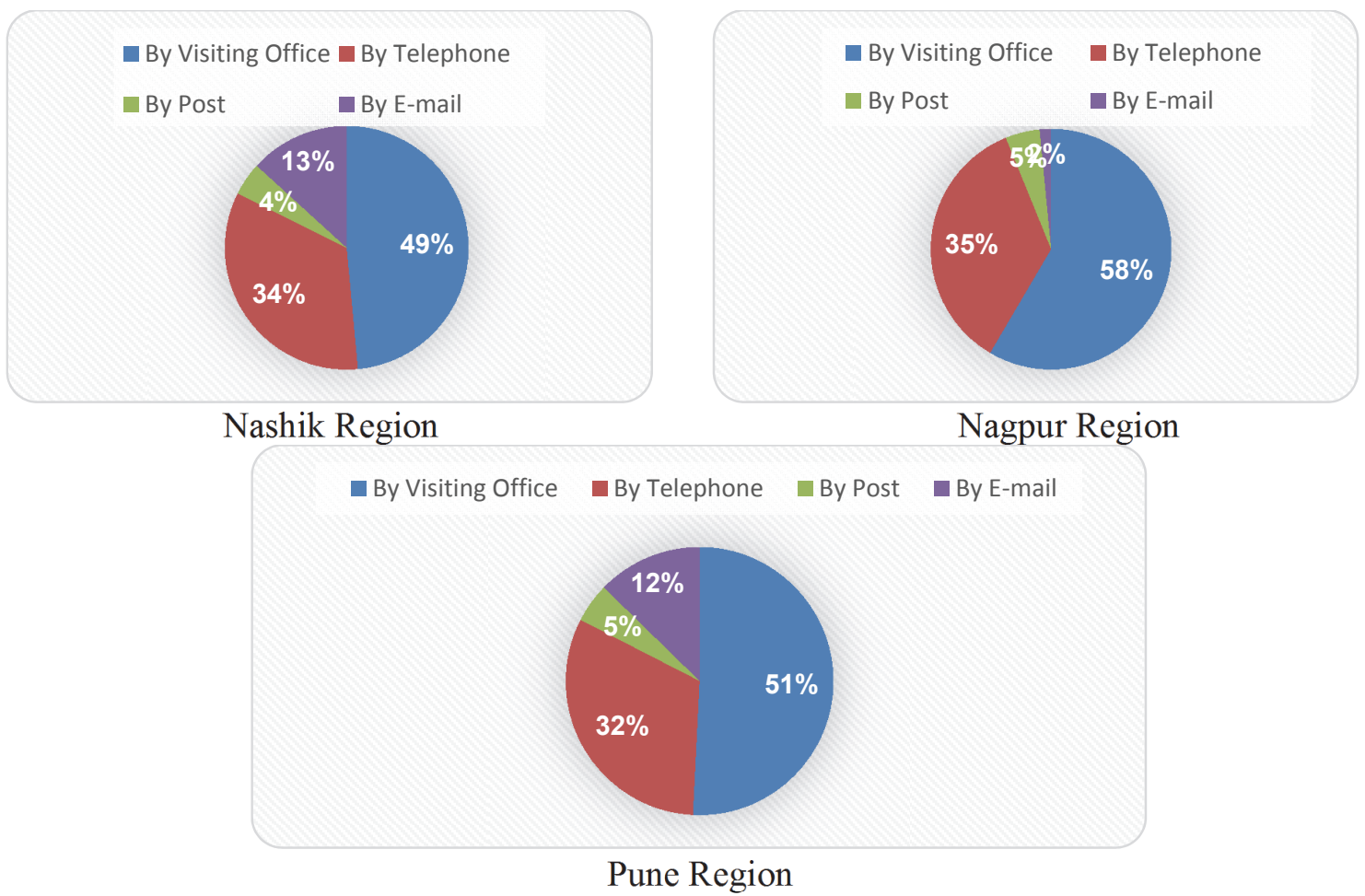

Fig. 2. Preferred mode of Communication with the organization

\section{b. Factors influencing the purchase of house from MHADA:}

Customers were asked about the reason behind the purchase of housing from MHADA rather than from a private builder / agency. Customers were allowed to provide multiple reasons. Multiple reasons provided by the customers included affordable rates, less documentation, safe and secure transactions, prompt service, construction quality, location and ease of obtaining loans. Responses provided by the customers are shown in Fig. 3.

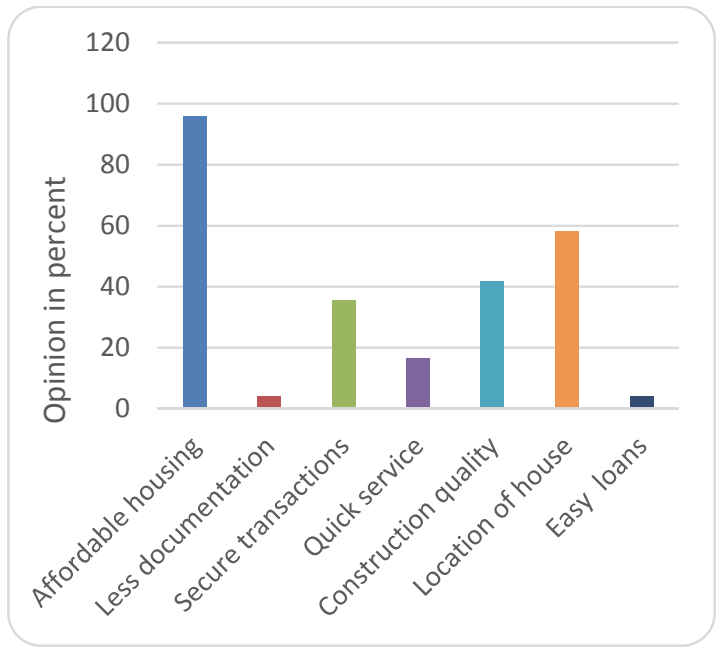

Amravati Region

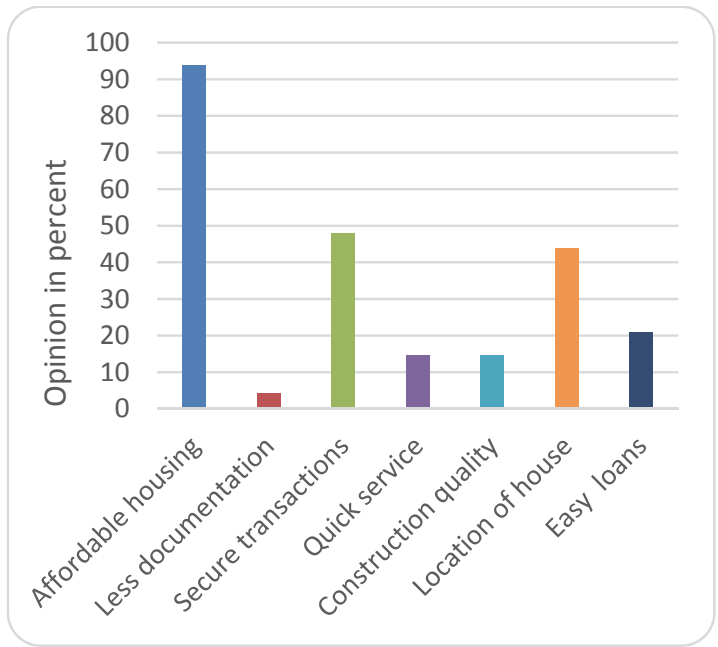

Aurangabad Region 


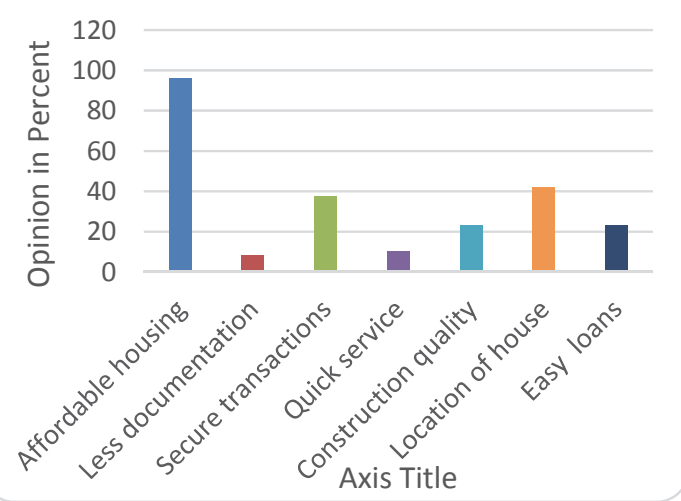

Konkan Region

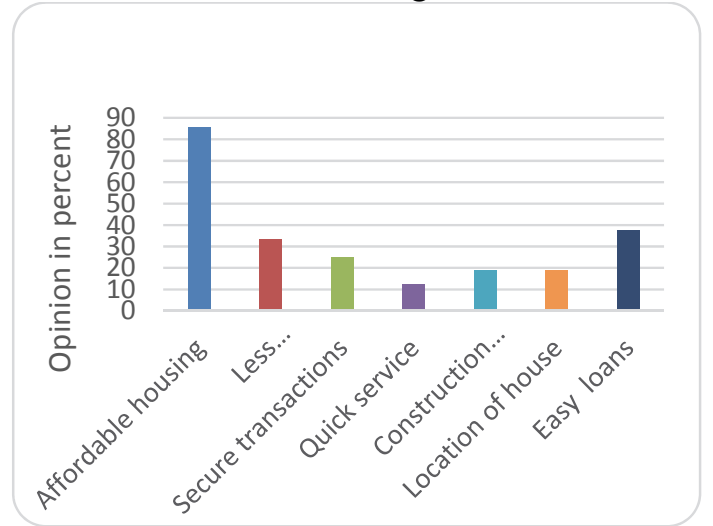

Nashik Region

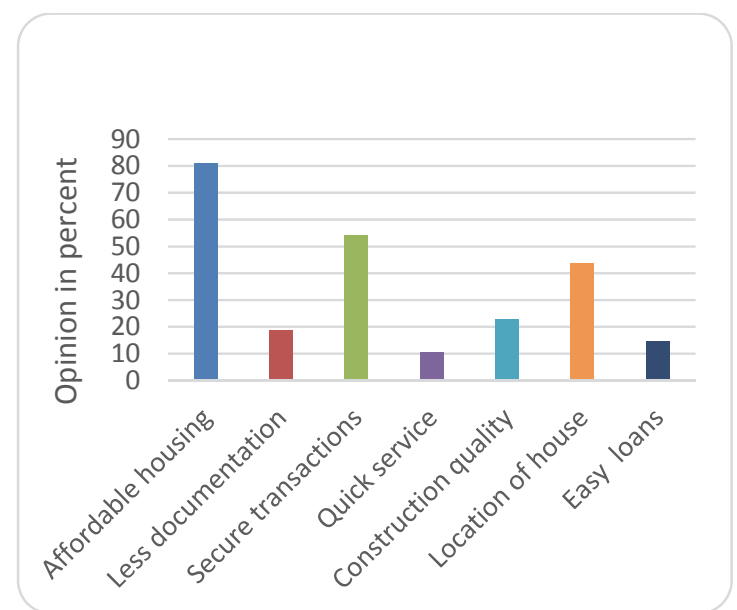

Mumbai Region

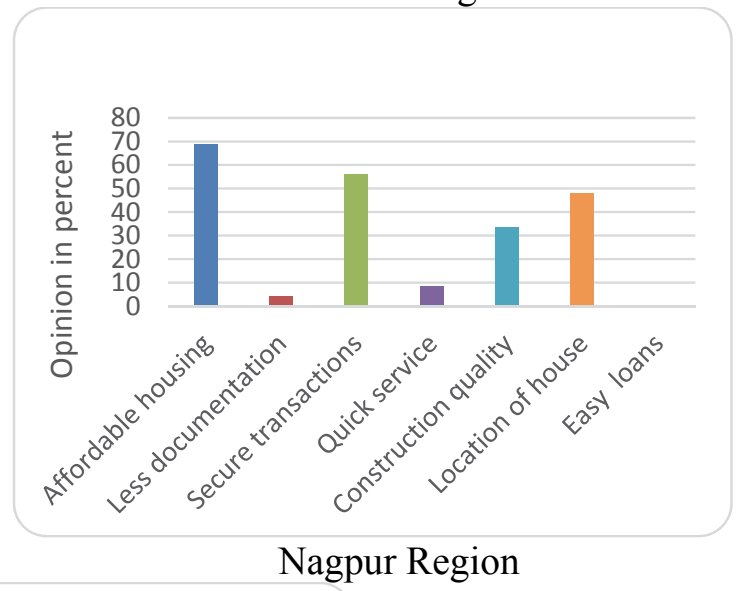

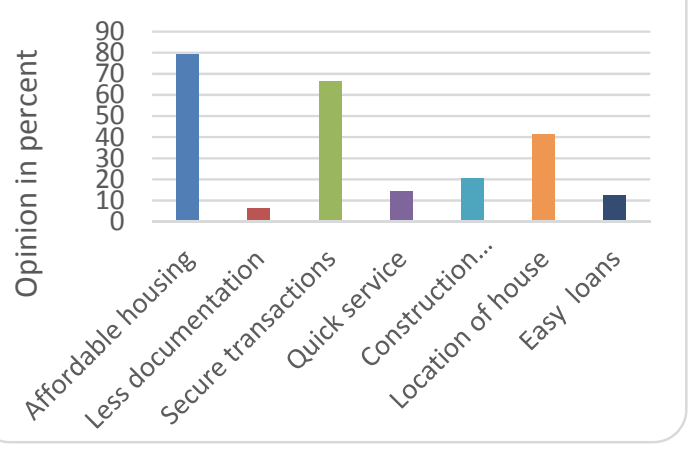

Pune Region

Fig. 3. Factors influencing purchase of housing from MHADA

Customer responses reveal that majority of the customers have preferred MHADA over other private agencies citing affordable housing rates. The other important factors influencing the purchase are secure transactions and locality of the house. These responses are in line with the basic motto of MHADA (i.e. providing comprehensive and coordinated approach to the housing problems faced by the people of the state). The organization should concentrate on other factors for influencing the purchase.

\section{c. Expectations about additional e-services:}

Customers were enquired about additional e-services they expect from the organization. Responses indicate that customers would like the organization to provide a variety of e-services. Majority of the 
customers expect that the organization should provide SMS alerts and prepare a mobile app that will facilitate interactions with the organization. The expectations of the customers are shown in the Fig. 4.

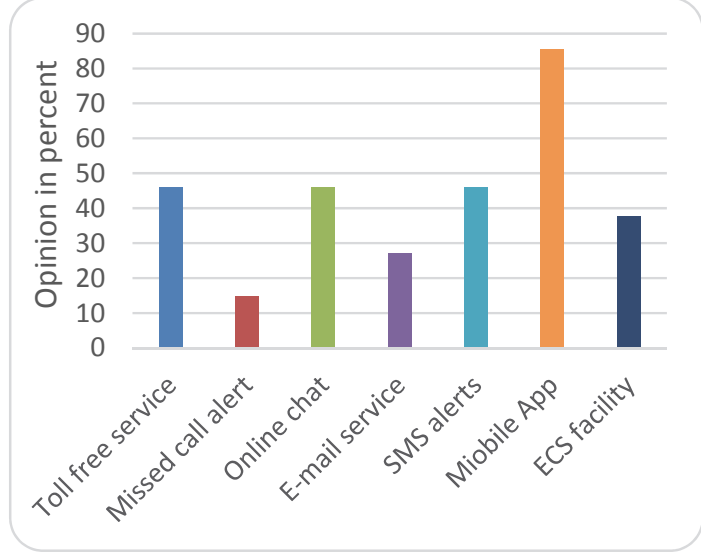

Amravati Region
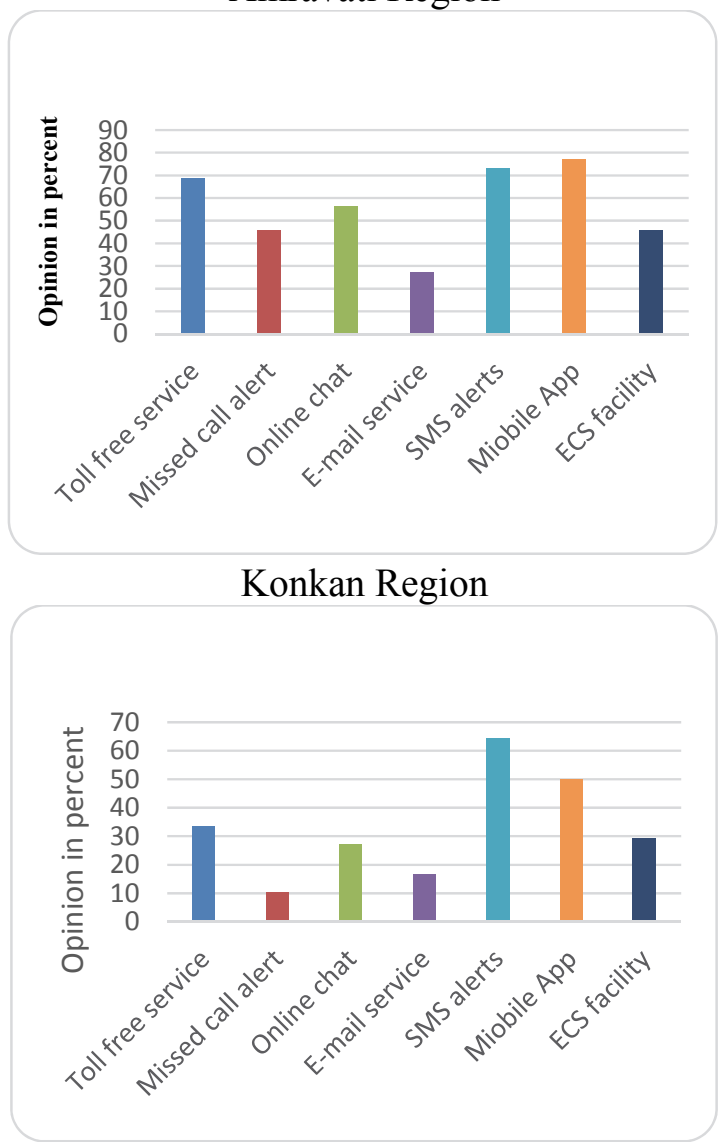

Nashik Region

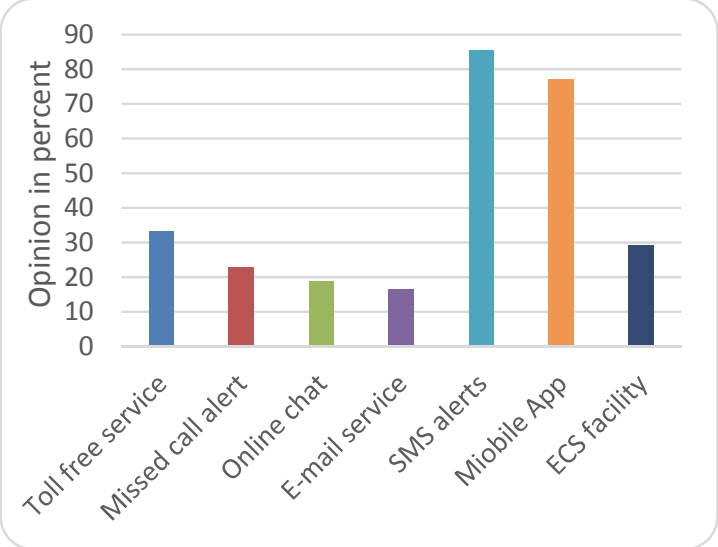

Aurangabad Region

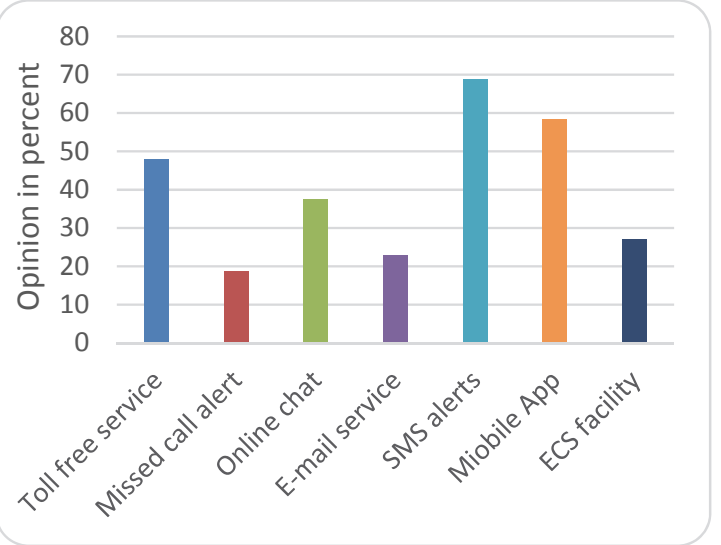

Mumbai Region

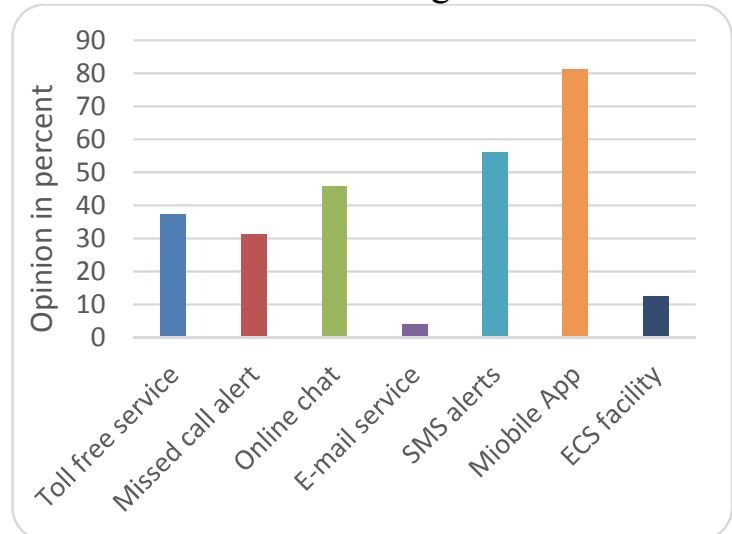

Nagpur Region 


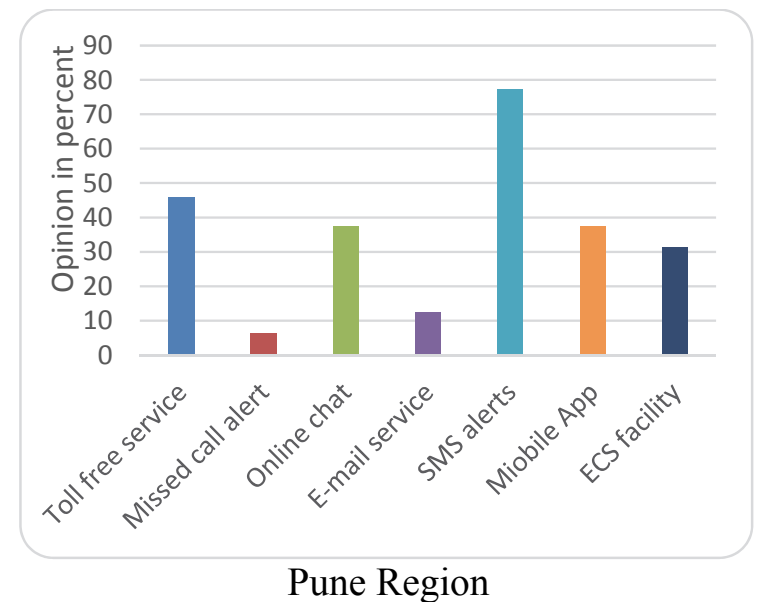

Fig. 4. Additional e-services expected by the customers

\section{Conclusion}

It is observed that internet users with higher income and education level are more likely to participate in the online process (Reddick, 2011). The current study reveals that customers belonging to the high and middle income group are more inclined towards Online Mitra system while those belonging to Low and Economically Weaker Section are more comfortable with Standardized Process. This pattern is probably due to the fact that customers belonging to LIG and EWS are mostly uneducated and do not have access to basic computing facilities.

There are several benefits associated with providing e-services to the customers (Kumar et. al. 2007). Some of these include easy access to information and services, reduction in number of customers at service counters, savings in time and cost of labor, increase in transparency, accountability and trust, avoid corruption etc. More and more processes should be standardized and modern e-practices should be incorporated to increase customer satisfaction.

In order to enhance the role of Information and Communication Technology (ICT) and ease of communication with the organization, various techniques such as appearance of the organization on social media, launching of mobile app, providing SMS alerts, online payments for every transaction, making the portal more interactive, installing self-service kiosks in colonies etc. may be adopted. Although some of the initiatives such as installation of self-service kiosks appear to be costly, the associated costs can be reduced by display of advertisements and tie up with other service providers.

There are some limitations in this study. Certain demographic variables such as location, education, sex, age etc. have not been considered while collecting the customer responses which are likely to influence the use of new digital media. Secondly the study has not considered factors such as fines / penalties levied on the customers, social issues such as corruption etc. which are also likely to influence the opinion of the customers. Additionally analysis of other customer expectations (discussed in section 5) can also be carried out on the basis of income group.

In spite of these limitations we believe that this study has been able to focus on appropriate e-Governance practices for improving the customer satisfaction and has highlighted the areas that can be worked upon by the organization. 


\section{Acknowledgements}

The authors would like to extend their profound gratitude towards Hon. Secretary, Maharashtra Housing and Area Development Authority (MHADA) for permitting the research work and Chief Officers and employees of all regional boards for extending their whole hearted support during the survey. The authors would also like to thank the customers of all income groups for their enthusiastic participation in the survey.

\section{References}

Bournaris, T., Manos, B., Moulogianni, C., Kiomourtzi, F., \& Tandini, M. (2013). Measuring Users Satisfaction of an e-Government portal. Procedia Technology, 8, 371-377.

Definition of e-Governance on UNESCO portal: http://portal.unesco.org/ci/en/ev.php-

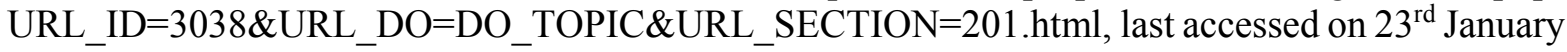
2017.

Dwivedi, S. K., \& Bharti, A. K. (2010). E-governance in India: Problems and acceptability. Journal of Theoretical \& Applied Information Technology, 17(1), 37-43.

Garg, Y., Dhagat, N. \& Shrivastava, B. (2014). Housing quality and customer satisfaction with reference to delivery methods, Global Journal of Engineering, Design \& Technology, 3(1), 1-4.

Hatto, P. (2010). Standards and standardization handbook. European Commission.

Hwang, C.L., \& Yoon, K.P. (1981) Multiple attribute decision making: methods and applications. New York: Springer-Verlag.

Joshi, A.S., Deshpande, V.S. \& Pawar, P.J. (2017). Identification of factors influencing the performance of government organizations and undertakings in India using Analytic Hierarchy Process. International Journal of Services Sciences. In Press.

Kumar, V., Mukerji, B., Butt, I., \& Persaud, A. (2007). Factors for successful e-government adoption: A conceptual framework. Electronic Journal of E-government, 5(1), 63-76.

Linacre, S. (2011) Keynote Address - Strategies for Standardization of Methods and Tools - How to get there: Statistics Canada's International Methodological Symposium. Catalogue no. 11-522-XCB

Mary, F. J. E., \& Surulivel, S. T. (2014). A study on buyer satisfaction in residential apartment with reference to VGN Infra Pvt. Ltd. International Research Journal of Business and Management, 8289.

Mistry, J. J., \& Jalal, A. (2012). An empirical analysis of the relationship between e-government and corruption. The International Journal of Digital Accounting Research, 12, 145-176.

Mustafa, A., \& Ghazali, M. (2012). Issues in housing delivery systems and customer satisfaction. Elixir Marketing Mgmt., 48, 9395-9399.

R. NAZ (2009), E-Governance for Improved Public Service Delivery in Fiji. Journal of Service Science and Management, 2(3), 190-203.

Official Circular No. 229 dated $14^{\text {th }}$ January 2016 issued by Secretary, MHADA Mumbai, Maharashtra State, India.

Oliver, R. L. (1999). Whence consumer loyalty? the Journal of Marketing, 63, 33-44.

Oliver, R. L. (1993). Cognitive, affective, and attribute bases of the satisfaction response. Journal of consumer research, 20(3), 418-430.

Oliver, R. L., Rust, R. T., \& Varki, S. (1997). Customer delight: foundations, findings, and managerial insight. Journal of retailing, 73(3), 311-336.

Rao, R. V. (2007). Decision making in the manufacturing environment: using graph theory and fuzzy multiple attribute decision making methods. Springer Science \& Business Media.

Rathod, P., Bhatt, R. \& Pitroda, J. (2016). Study of factors affecting customer satisfaction for residential flats in Surat and Ahmedabad city in Gujarat region of India. International Research Journal of Engineering and Technology (IRJET), 3(3), 1-8.

Reddick, C. G. (2005). Citizen interaction with e-government: From the streets to servers?. Government Information Quarterly, 22(1), 38-57. 
Reddick, C. G., \& Jaramillo, P. A. (2014). New digital media use and preferences for government: a survey of Canadians. Electronic Government, An International Journal, 11(1/2), 39-58.

Reddick, C. G. (2011). Citizen interaction and e-government: Evidence for the managerial, consultative, and participatory models. Transforming Government: People, Process and Policy, 5(2), 167184.

Shang, S. S. (2014). Assessment of E-government Service Quality under User Satisfaction Orientation: The Establishment of E-Govqual Model. Asian Journal of Business Management, 6(2), 111-118.

Singh, G., Pathak, R. D., Naz, R., \& Belwal, R. (2010). E-governance for improved public sector service delivery in India, Ethiopia and Fiji. International Journal of Public Sector Management, 23(3), 254-275.

Singla, S. K., \& Aggarwal, H. (2014). Status of e-governance in the state of Punjab (India): an analytical study. Electronic Government, An International Journal, 11(1/2), 1-15.

Tolbert, C. J., \& Mossberger, K. (2006). The effects of e-government on trust and confidence in government. Public administration review, 66(3), 354-369.

Welch, E. W., Hinnant, C. C., \& Moon, M. J. (2005). Linking citizen satisfaction with e-government and trust in government. Journal of public administration research and theory, 15(3), 371-391.

West, D. M. (2004). E-government and the transformation of service delivery and citizen attitudes. Public administration review, 64(1), 15-27.

Warale, P. N., \& Diwakar, H. (2015). A Study of Citizen Satisfaction for e-Governance Initiative SETU in Maharashtra (India). International Journal of Computer Applications, 124(17).

Yaghoubi, N. M., Haghi, A., \& Asl, S. (2011). e-Government and citizen satisfaction in Iran: Empirical study on ICT offices. World Applied Sciences Journal, 12(7), 1084-1092.

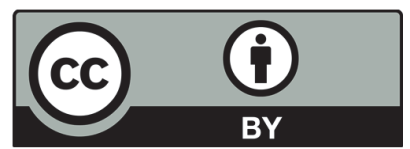

(C) 2017 by the authors; licensee Growing Science, Canada. This is an open access article distributed under the terms and conditions of the Creative Commons Attribution (CC-BY) license (http://creativecommons.org/licenses/by/4.0/). 